\title{
Viral FLICE inhibitory protein of Rhesus monkey rhadinovirus inhibits apoptosis by enhancing autophagosome formation
}

\author{
Krit Ritthipichai ${ }^{1}$, Yuchen Nan ${ }^{1}$, loannis Bossis², Yan-Jin Zhang ${ }^{1 *}$ \\ From 13th International Conference on Malignancies in AIDS and Other Acquired Immunodeficiencies \\ (ICMAOI) \\ Bethesda, MD, USA. 7-8 November 2011
}

Rhesus monkey rhadinovirus (RRV) is a gamma-2 herpesvirus closely related to human herpesvirus 8 (HHV8). RRV encodes viral FLICE inhibitory protein (vFLIP), which has death effector domains. Little is known about RRV vFLIP. This study intended to examine its function in apoptosis. Here we found that RRV vFLIP inhibits apoptosis induced by tumor necrosis factor- $\alpha$ (TNF- $\alpha$ ) and cycloheximide. In HeLa cells with vFLIP expression, the cleavage of poly [ADP-ribose] polymerase 1 (PARP-1) and activities of caspase 3, 7, and 9 were much lower than those in controls. Cell viability of HeLa cells with vFLIP expression was significantly higher than control cells after apoptosis induction. However, RRV vFLIP appears unable to induce NF- $\kappa$ B signaling when tested using NF- $\kappa$ B reporter assay. RRV vFLIP was able to enhance cell survival under starved conditions or apoptosis induction. At early time points after apoptosis induction, autophagosome formation was enhanced and LC3-II level was elevated in cells with vFLIP and, when autophagy was blocked with chemical inhibitors, these cells underwent apoptosis. Full length of vFLIP is needed for the function against apoptosis as truncation variants of vFLIP were unable to block apoptosis induction. Moreover, RRV latent infection of BJAB B-lymphoblastoid cells protects the cells against apoptosis by enhancing autophagy to maintain cell survival. Knockdown of vFLIP expression in the RRV-infected BJAB cells with siRNA abolished the protection against apoptosis. These findings indicate that vFLIP protects cells against apoptosis by enhancing autophagosome formation to extend cell survival. The finding of vFLIP's inhibition of

\footnotetext{
* Correspondence: zhangyj@umd.edu

${ }^{1}$ Molecular Virology Laboratory, University of Maryland, College Park, MD, USA

Full list of author information is available at the end of the article
}

apoptosis via the autophagy pathway provides insights of vFLIP in RRV pathogenesis.

\section{Author details}

${ }^{1}$ Molecular Virology Laboratory, University of Maryland, College Park, MD, USA. ${ }^{2}$ Cell Biology Laboratory, VA-MD Regional College of Veterinary Medicine and Maryland Pathogen Research Institute, University of Maryland, College Park, MD, USA.

Published: 19 April 2012

\section{doi:10.1186/1750-9378-7-S1-P44}

Cite this article as: Ritthipichai et al:: Viral FLICE inhibitory protein of Rhesus monkey rhadinovirus inhibits apoptosis by enhancing autophagosome formation. Infectious Agents and Cancer 2012 7(Suppl 1): P44.
Submit your next manuscript to BioMed Central and take full advantage of:

- Convenient online submission

- Thorough peer review

- No space constraints or color figure charges

- Immediate publication on acceptance

- Inclusion in PubMed, CAS, Scopus and Google Scholar

- Research which is freely available for redistribution
() Bïomed Central
C Biomed Central

() 2012 Ritthipichai et al; licensee BioMed Central Ltd. This is an Open Access article distributed under the terms of the Creative Commons Attribution License (http://creativecommons.org/licenses/by/2.0), which permits unrestricted use, distribution, and reproduction in any medium, provided the original work is properly cited. 